\title{
Fen Bilgisi Öğretmen Adaylarının Türkiye İstatistiki Bölge Birimlerine Göre Evrensel Fen Okuryazarlık Düzeyi
}

\author{
Pre-Service Science Teachers' Universal Science Literacy Levels Across \\ The Statistical Regional Units \\ Şendil CAN ${ }^{* *}$, Cüneyd ÇELIK ${ }^{* * *}$ \\ • Geliş Tarihi: 07.03.2019 • Kabul Tarihi: 12.09.2019 • Çevrimiçi Yayın Tarihi: 25.09.2019
}

\section{$\ddot{O} \mathbf{z}$}

$\mathrm{Bu}$ çalışmanın amacı, Türkiye İstatistiki Bölgelerinin farklı birimlerinde öğrenim görmekte olan fen bilgisi öğretmen adaylarının Evrensel Fen Okuryazarlığı'nın hangi düzeyde olduğu; evrensel fen okuryazarlık düzeyine istatistiki bölge birimleri, cinsiyet ve sınıf düzeyi değişkenlerinin etkisini araştırmaktır. Araştırma, 2015-2016 Eğitim-Öğretim Yılı Bahar Yarıyılında Türkiye'nin 12 farklı istatistiki bölge birimlerinde yer alan 20 üniversitenin eğitim fakültelerinde öğrenim gören 1088 birinci sınıf ve 920 dördüncü sınıf olmak üzere, toplam 2008 (Kadın:1564; Erkek:444) fen bilgisi öğretmen adayı ile yürütülmüştür. Elde edilen bulgularda, tüm boyutlarda fen bilgisi öğretmen adaylarının evrensel fen okuryazarlık düzeyi yüksek bulunmuștur. Ayrıca kadın öğretmen adaylarının erkeklere göre, 4. sınıf öğretmen adaylarının da 1. sınıflara göre evrensel fen okuryazarlık düzeyinin daha yüksek olduğu sonucuna ulaşılmıştır. Diğer taraftan Evrensel Fen Okuryazarlık düzeyi Türkiye istatistiki bölge birimlerine göre farkl1lık oluşturduğu görülmüştür.

Anahtar Kelimeler: EFOYÖ, evrensel fen okuryazarlığı, fen bilgisi öğretmen adayı, Türkiye istatistiki bölge birimleri

Atıf:

Can, Ş., ve Çelik, C. (2020). Fen Bilgisi Öğretmen Adaylarının Türkiye istatistiki bölge birimlerine göre Evrensel Fen Okuryazarlık Düzeyi. Pamukkale Üniversitesi Eğitim Fakültesi Dergisi, 49, 112-133. doi: 10.9779/pauefd.536777.

\footnotetext{
* Bu çalışma yüksek lisans tezinin bir bölümü olup Muğla Sitkı Koçman Üniversitesi Bilimsel Araştırma Projeleri birimi tarafından desteklenmiştir. Ayrıca 2018 yılında 11. Uluslararası Eğitim Araştırmaları Kongresinde sözlü bildiri olarak sunulmuştur.

${ }_{* *}$ Prof. Dr., Muğla Sitkı Koçman Üniversitesi Eğitim Fakültesi, Matematik ve Fen Bilimleri Eğitimi Bölümü Muğla, Türkiye. ORCID: 0000-0001-9313-7273 csendil@mu.edu.tr

Arş. Gör. Muğla Sitkı Koçman Üniversitesi Eğitim Fakültesi, Matematik ve Fen Bilimleri Eğitimi Bölümü Muğla, Türkiye. ORCID: 0000-0002-1188-6260, cuneydcelik@mu.edu.tr

*** Arş. Gör. Muğla Sitkı Koçman Üniversitesi Eğitim Fakültesi, Matematik ve Fen Bilimleri Eğitimi Bölümü Muğla, Türkiye. ORCID: 0000-0002-1188-6260, cuneydcelik@mu.edu.tr
} 


\begin{abstract}
The purpose of the current study is to determine the Universal Science Literacy level of pre-service science teachers attending universities located in different units of Turkish Statistical Regions and to investigate whether the universal science literacy level varies significantly depending on the variables of gender and grade level. The current study was carried out with the participation of a total of 1088 first-year pre-service science teachers and 920 fourth-year pre-service science teachers enrolled in the education faculties of 20 different universities from 12 different statistical regions of Turkey in the spring term of 2015-2015 academic year. The total number of the participants is 2008 and 1564 of them are females and 444 are males. The findings revealed that the pre-service science teachers' universal science literacy level is high in all the dimensions. Moreover, it was concluded that the female participants' universal literacy level is higher than that of the male participants and the fourth-year students' universal literacy level is higher than that of the first-year students. On the other hand, the level of universal science literacy was found to be varying depending on the units of Turkish Statistical Regions.
\end{abstract}

Key Words: Universal science literacy, USLS, pre-service science teacher, Turkish statistical regional units

\title{
Cited:
}

Can, Ş., \& Çelik, C. (2020). Pre-Service Science Teachers' Universal Science Literacy levels across the statistical regional units. Pamukkale Üniversitesi Eğitim Fakültesi Dergisi, 49, 112-133. doi: 10.9779/pauefd.536777. 


\section{Giriş}

"Bilim nedir?" sorusu yıllardır bilim insanlarının ortak bir karara varmakta zorluk çektiği bir soru olmuştur. Ortak bir tanım üzerinde birleşilememesi, bilimin sürekli gelişen, kapsadığı konular yönünden bir sınırı olmayan, çok yönlü ve dinamik bir yapıda olmasından kaynaklanmaktadır (Bora, Aslan ve Çakıroğlu, 2006; Doğan, Çakıroğlu, Bilican ve Çavuş, 2012). Bilim, Doğu'da yer alan Mısır, Mezopotamya, Babil ve Çin uygarlıklarında parlak dönemlerini yaşarken zamanla Antik Grek dünyasına, oradan da Avrupa'ya yayılmıştır. Bilim, Avrupa'da etkinliğini yitirirken 8. yy.'dan itibaren İslam dünyasında yükselmeye başlamıştır. Bu sirkülasyon, bilimin kümülatif bir şekilde ilerlemesiyle Doğu-Batı arasında gidip gelerek günümüze kadar süre gelmiştir (Topdemir ve Ünat, 2012). Bilgi çağı olarak adlandırılan 19. yüzyılda bilim ve teknolojideki hızlı gelişim, toplumların yapısında birçok değişimi de beraberinde getirirken, eğitimin de bu hızlı gelişime ayak uydurmasını zorunlu kılmıştır. Özellikle, 1950'li yıllardan sonra birçok ülke yönetimi, bilimsel bilgiyi gelecekteki ekonomik yarışın anahtarı olarak görmüş ve toplumu oluşturan bireylerin bilimle ilgili bilgi ve becerilerini yükseltme çabası içine girmiştir (Rodrigues ve Oliveira, 2008).

Bilginin büyük bir hızla arttığı 21. yy.'da devletler, bilim ve teknolojideki hızlı gelişmeleri takip etme ve bu gelişmelere ayak uydurma ihtiyacı hissetmektedir. Bilgi toplumları, bu gelişmeleri kendi geleceğinin faydası için çok önemsemişlerdir. Bu durumu önemli bulan ülkeler, gençlerini sürekli değişim ve gelişim içinde olan, bilimi takip eden, yeniliklerin ve gelişmelerin farkında olan, bu gelişmelerin kendisine nasıl katkı sağlayacağını düşünen ve bunu uygulamaya geçirebilen birey olarak yetiştirmek ve eğitmek istemektedir (Özdem, Çavaş, Çavaş, Çakıroğlu ve Ertepınar, 2010). Her ülke, kendi kültürüne ve sosyolojik yapısına uygun, ülke politikası doğrultusunda vatandaşlar yetiştirmek için belirli kıstaslar belirlemiş ve hedefledikleri bir öğrenci profili ortaya koymuşlardır. Bu profile sahip öğrenciler, okuryazar bireyler olarak adlandırılmışlardır.

Zaman içinde toplumda ki bireylerin okuryazar olarak yetiştirilmesinin önemini fark eden bilim insanları, okuryazarlığın farklı yönleri üzerinde duran çalışmalar ortaya koyduğu görülmüştür. Bilgi okuryazarliğı (Başaran, 2005; Kurbanoğlu ve Akkoyunlu, 2001; Özmusul, 2012), Fen okuryazarlı̆̆l (Can ve Öner, 2008; Kaya ve Bacanak, 2013; Özdemir, 2010), Bilim okuryazarlığı/Bilimsel okuryazalık (Kılıç Bağcı, Haymana, Bozyılmaz, 2008; Tunç Sahin ve Say, 2010), Teknoloji okuryazarliğ (Canbaz, 2010; Çoklar ve Şahin, 2014), Fen ve Teknoloji okuryazarlığı (Doğan ve Yılmaz, 2013; Duban, 2010; Yetişir, 2007), Matematik okuryazarlığ (Duran ve Bekdemir, 2013; Özsoy Güneş, Çıngıl Barış, Kırbaşlar, 2013), Çevre okuryazarlı̆̆l (Balkan Kıyıcı, Atabek Yiğit ve Darçın, 2014; Karatekin ve Aksoy, 2012) bu çalışmalara verilen örneklerden bazılarını oluşturmaktadır.

$\mathrm{Bu}$ okuryazarlık türlerinden özellikle fen okuryazarlığının, bireylerin çevrelerini daha iyi anlayabilmeleri, bilim ve gündelik hayat arasında ilişki kurarak yaşamlarını daha anlamlı sürdürebilmeleri, bilimsel kültüre katkı sağlamaları ve toplumda etkin bir rol üstlenerek toplumun gelişmişlik düzeyini arttırabilmeleri açılarından çok önemli bir yere sahip olduğu düşünülmektedir. $\mathrm{Bu}$ sebepten dolayı fen öğretim programları aracıllı̆ıyla fen okuryazarı bireylerin yetiştirilmesi dünya üzerinde birçok ülkenin önceliği haline gelmiştir (Turgut, 2007). Özellikle 1980'li y1llardan itibaren uluslararası alanda fen eğitimcileri ve fen eğitim kuruluşları, fen programlarında yer alan fen okuryazarlığını tanımlamaya ve şekillendirmeye çalışmışlardır (Bybee, 1997, akt. Turgut, 2007; Dani, 2009; Millar ve Osborne, 1998; Miller, 1998; NRC, 1996; Shamos, 1995). Bu sebeple ilgili hedef kitlenin fen okuryazarlık düzeyi, fen okuryazarlı̆gı algısı, fen okuryazarlığına ilişkin düşüncesi ve fen okuryazarı bireyin sahip olması gereken özelliklerin tespit edilmesi, fen okuryazarlığının tanımlanması ve şekillendirilmesinde önem arz etmektedir. Bu önem dikkate alınarak, ilgili grupların 
durumu hakkında fikir sahibi olmak için; fen okuryazarlık düzeylerinin tespit edilmesi için ölçeklerin geliştirildiği (Fives, Huebner, Birnbaum ve Nicolich, 2014; Glynn and Koballa, 2006; Laugksch ve Spargo, 1996; Mun, Shin, Lee, Kim, Choi, Choi ve Krajcik, 2015), fen okuryazarlığının yapısını oluşturacak kuramsal temellerin öne sürüldüğü (Choi, Lee, Kim ve Krajcik, 2011; Hodson, 2003), öğrencilerin fen okuryazarlık algılarını arttıracak tavsiyelerin ve önerilerin getirildiği (Lederman, Antink, Bartos, 2014; Liu, 2009; Norris ve Philips, 2003), bireylerin fen okuryazarlık düzeylerinin ölçüldüğü (Bacanak ve Gökdere, 2009; Laugksch ve Spargo, 1996; Miller, 2002; Mun, Shin vd., 2015; Özdemir, 2010), bireylerin fen okuryazarlık seviyelerinde farklı değişkenlerin etkisinin araştırıldığı (Anagün, 2011; Foster ve Shiel-Rolle, 2011; Sarıbaş, 2015), fen öğretim programlarının ve ders kitaplarının fen okuryazarlığı açısından değerlendirildiği (BouJaoude, 2002; Erdoğan ve Köseoğlu, 2012; Wei ve Thomas, 2006; Wilkinson, 1999) ve fen okuryazarllğının tarihsel ve kavramsal gelişim sürecinin ele alındığı (Choi vd., 2011; Deboer, 2000; Hurd, 1998; Laugksch, 2000; Miller, 1983; Turgut, 2007) araştırmalar yapıldı̆̆ı görülmektedir.

$\mathrm{Bu}$ çalışmalardan, Laugksch ve Spargo'nun (1996) geliştirmiş olduğu “Temel Fen Okuryazarlık" ölçeği, Türkiye literatüründe bireylerin fen okuryazarlık düzeylerinin tespit edilmesinde (Duruk, 2012; Huyugüzel Çavaş, 2009; Ulutaş, 2009; Yetişir, 2007) en sıklıkla kullanılan ölçeklerden biri olduğu gözlenmiştir. Bu ölçeğin, 1990'lı ve 2000'li yılların fen okuryazarı bireyin sahip olması gereken özellikleri üzerine kurulmasından, fen okuryazarı bireyden beklenen taleplerin zaman içerisinde değişmesinden ve ülkemiz fen öğretim programının 2013 ve 2018 yılında yenilenmesinden dolayı, yenilenen fen okuryazarlık anlayışını temsil edecek güncel bir ölçeğin varlığına ihtiyaç duyulmuştur (Çelik ve Can, 2017).

2013 ve 2018 yılında yenilenen fen bilimleri öğretim programlarında fen okuryazarlığı, sadece bilişsel bilgi anlayışıyla sınırlı kalmayıp, duyuşsal becerilerinde önemli olduğu bir anlayış haline bürünmüştür. Ayrıca program, 21. yüzyı1 becerileriyle zenginleştirilip analitik düşünme, iletişim ve takım çalışması, karar verme ve girişimcilik gibi becerileri daha fazla vurgulamaya önem vermiştir. Aşağıda yer alan Tablo 1'de, Evrensel Fen Okuryazarlığı Ölçeğini (EFOYÖ) oluşturan faktörler ile fen bilimleri öğretim programının ön plana çıkardığı alt öğrenme alanlarının bir karşılaştırılması yapılmıştır.

Tablo 1. Evrensel fen okuryazarlı̆̆ına ilişkin faktörler ve fen bilimleri öğretim programı alt öğrenme alanları tablosu

\begin{tabular}{|c|c|}
\hline Fen Bilimleri Öğretim Programını oluşturan alt & $\begin{array}{c}\begin{array}{c}\text { Evrensel Fen Okuryazarlığı Ölçeği’ni oluşturan } \\
\text { faktörler }\end{array}\end{array}$ \\
\hline $\begin{array}{l}\text { Beceri: } \\
\quad \text { Iletişim } \\
\quad \text { Takım Calısması }\end{array}$ & Illetişim ve işbirliği \\
\hline Analitik Düsünme & Sistematik düşünme \\
\hline Karar verme & Planlama/Denetleme \\
\hline Bilimsel Süreç Becerileri* & Değerlendirme \\
\hline $\begin{array}{l}\text { FTTÇ: } \\
\quad \text { Sosyobilimsel konular } \\
\text { Bilimin doğast }\end{array}$ & $\begin{array}{l}\text { Sosyobilimsel sorumluluk } \\
\text { Bilimsel bilginin karakteristiği }\end{array}$ \\
\hline $\begin{array}{l}\text { Bilim ve Teknoloji ilisskisi } \\
\text { Bilimin Toplumsal Katklsl }\end{array}$ & Fen ve toplum/Bilim ruhu \\
\hline Sürdürülebilir Kalkınma Bilinci & Ekolojik dünya görüşü \\
\hline
\end{tabular}

Evrensel Fen Okuryazarlığı Ölçeği’nin hem fen bilimleri öğretim programının vizyonuyla örtüşmesi hem de yenilenen programdaki fen okuryazarlık boyutlarının birçoğu ile uyuşması, bu ölçme aracının fen okuryazarlığı konusundaki geçerliliğini göstermektedir. Bu bakımdan fen bilgisi 
öğretmen adaylarının evrensel fen okuryazarlık düzeyinin, güncel bir ölçme aracı ile belirlenmesinin; çalışmaya önem katacağı gibi araştırma örnekleminin Türkiye İstatistiki Bölge Birimleri Sınıflamasına (İBBS) göre belirlenen 12 bölgede yer alan fen bilgisi öğretmen adayları üzerinde uygulanması da çalışmaya ayrıca özgünlük katacağı düşünülmektedir.

Bu bağlamda bu çalışmanın amacı, Türkiye İBB'nin farklı birimlerinde öğrenim görmekte olan fen bilgisi öğretmen adaylarının Evrensel Fen Okuryazarlık düzeyini belirlemek, bununla birlikte evrensel fen okuryazarlık düzeyinin IBB, cinsiyet, sınıf düzeyi değişkenlerinin etkisini tespit etmektir. Bu amaç doğrultusunda araştırmada şu sorulara cevap aranmaktadır.

1. Türkiye'de fen bilgisi öğretmen adayları, evrensel fen okuryazarlığı boyutlarına göre hangi düzeydedir?

2. Türkiye'de, fen bilgisi öğretmen adaylarının evrensel fen okuryazarlık düzeyi, farklı istatistiki bölge birimlerine göre anlamlı farklılık göstermekte midir?

3. Türkiye'de, fen bilgisi öğretmen adaylarının evrensel fen okuryazarlık düzeyi, cinsiyete göre anlamlı farkl11ı göstermekte midir?

4. Türkiye'de, fen bilgisi ögretmen adaylarının evrensel fen okuryazarlık düzeyi, sınıf düzeyine göre anlamlı farkl11ık göstermekte midir?

\section{Yöntem}

Araştırma tarama modelinde yürütülmüştür. Tarama modelli araştırmalar, bir araştırmanın evreninin eğilim, tutum ya da görüşlerini bu evrendeki bir örneklemle çalışarak nicel ya da sayısal olarak tanımlamaya çalışan desenlerdir (Creswell ve Clark, 2015).

\section{Evren-Örneklem}

Araştırmanın evrenini, 2015-2016 Eğitim-Öğretim yılında Türkiye'de üniversitelerin eğitim fakültelerinde öğrenim gören fen bilgisi öğretmen adayları oluşturmaktadır. Örneklem ise 2015-2016 Eğitim-Öğretim Yılı Bahar Yarıyılında, 12 istatistiki bölgede ${ }^{1}$ yer alan 20 üniversitenin eğitim fakültelerindeki fen bilgisi öğretmenliği programında öğrenim gören 1. sınıf 1088 (\%54,2) ve 4. sinıf $920(\% 45,8)$ kişi olmak üzere toplam 2008 öğretmen adayından oluşmaktadır. Örneklemde yer alan katılımcıların dağılımlarına ilişkin bilgiler Tablo 2'de daha detaylı bir şekilde sunulmuştur.

Tablo 2. Türkiye İBBS'ye göre fen bilgisi öğretmen adaylarının dağılımı

\begin{tabular}{|c|c|c|c|c|c|c|c|c|}
\hline \multirow{2}{*}{$\begin{array}{l}\text { Bölge } \\
\text { No }\end{array}$} & \multirow{2}{*}{$\begin{array}{c}\text { İstatistiki Bölge } \\
\text { Birimleri } \\
\text { Sinıflaması } \\
\text { (İBBS-1. Düzey) }\end{array}$} & \multirow{2}{*}{$\begin{array}{c}\text { İstatistiki Bölge } \\
\text { Birimleri } \\
\text { Sınıflaması } \\
\text { (İBBS-2. Düzey) }\end{array}$} & \multicolumn{2}{|c|}{ 1. Sinıf } & \multicolumn{2}{|c|}{ 4. Sinıf } & \multicolumn{2}{|c|}{ Toplam } \\
\hline & & & $\mathbf{N}$ & $\%$ & $\mathbf{N}$ & $\%$ & $\mathbf{N}$ & $\%$ \\
\hline Bölge 1 & İstanbul & İstanbul & 60 & 3,0 & 50 & 2,5 & 110 & 5,5 \\
\hline Bölge 2 & Batı Marmara & $\begin{array}{l}\text { Balıkesir, } \\
\text { Çanakkale }\end{array}$ & 53 & 2,7 & 71 & 3,5 & 124 & 6,2 \\
\hline Bölge 3 & Ege & Denizli, Muğla & 110 & 5,6 & 118 & 5,8 & 228 & 11,4 \\
\hline Bölge 4 & Doğu Marmara & Bolu, Bursa & 113 & 5,6 & 66 & 3,3 & 179 & 8,9 \\
\hline Bölge 5 & Batı Anadolu & Ankara, Konya & 133 & 6,6 & 62 & 3,1 & 195 & 9,7 \\
\hline Bölge 6 & Akdeniz & $\begin{array}{l}\text { Adana, } \\
\text { Antalya }\end{array}$ & 111 & 5,5 & $\begin{array}{l}11 \\
2\end{array}$ & 5,6 & 223 & 11,1 \\
\hline
\end{tabular}

\footnotetext{
1 İstatistiki bölge birimleri, Avrupa Birliği uyum yasaları kapsamında bir ülkenin ekonomik, sosyal ve coğrafi yönden benzerlik gösteren birbirine komşu illerin bir bölge oluşturarak, bölgesel tabanlı istatistikleri ortaya koymak, sosyo-ekonomik analizler yapmak ve topluma yönelik bölgesel politikalar geliştirmek amacıyla Türkiye İstatistik Kurulumu (TÜIK) tarafından yapılan sınıflamadır (Yılmaz, Dericioğlu, Elliott, Özden, 2007).
} 


\begin{tabular}{|c|c|c|c|c|c|c|c|c|}
\hline Bölge 7 & Orta Anadolu & $\begin{array}{l}\text { Kayseri, } \\
\text { Kırşehir }\end{array}$ & 121 & 6,0 & 87 & 4,4 & 208 & 10,4 \\
\hline Bölge 8 & Bat1 Karadeniz & Kastamonu & 98 & 4,9 & $\begin{array}{c}10 \\
5\end{array}$ & 5,2 & 203 & 10,1 \\
\hline Bölge 9 & Doğu Karadeniz & Trabzon & 75 & 3,7 & 86 & 4,3 & 161 & 8,0 \\
\hline Bölge 10 & $\begin{array}{l}\text { Kuzeydoğu } \\
\text { Anadolu }\end{array}$ & Erzurum, Kars & 110 & 5,4 & 79 & 4,0 & 189 & 9,4 \\
\hline Bölge 11 & $\begin{array}{l}\text { Ortadoğu } \\
\text { Anadolu }\end{array}$ & Malatya & 59 & 3,0 & 42 & 2,0 & 101 & 5,0 \\
\hline \multirow[t]{2}{*}{ Bölge 12} & $\begin{array}{l}\text { Güneydoğu } \\
\text { Anadolu }\end{array}$ & Kilis & 45 & 2,2 & 42 & 2,1 & 87 & 4,3 \\
\hline & & Toplam & 1088 & 54,2 & 920 & 45,8 & 2008 & 100 \\
\hline
\end{tabular}

12 istatistiki bölge birimleri arasında en fazla katılım, sırasıyla Ege $(228 ; \% 11,4)$, Akdeniz (223; \%11,), Orta Anadolu (208; \%10,4) bölgelerinden; en az katılım ise sirasılyla Güneydoğu Anadolu (87; \%4,3), Ortadoğu Anadolu (101;\%5,0), İstanbul $(110 ; \% 5,5)$ bölgelerinden sağlanmıştır. Katılımcıların cinsiyet değişkenine göre dağılımları ise Tablo 3 'te verilmiştir.

Tablo 3. Katılımcıların cinsiyete göre dağılımı

\begin{tabular}{lcc}
\hline Cinsiyet & N & \% \\
\hline Kadın & 1564 & 77,9 \\
Erkek & 444 & 22,1 \\
\hline Toplam & 2008 & 100 \\
\hline
\end{tabular}

Örneklem grubunun cinsiyete göre dağılımlarında kadın öğretmen adayları $(1564 ; \% 77,9)$ erkek öğretmen adaylarından (444; \%22,1) daha yüksek oranda dağılım göstermiştir.

\section{Veri Toplama Aracı}

Evrensel Fen Okuryazarlığı Ölçeği, Mun, Shin, Lee, Kim, Choi, Choi ve Krajcik (2015) tarafından geliştirilip, Çelik ve Can (2017) tarafından Türkçe 'ye uyarlanmış 48 maddeden oluşan bir ölçektir. Paradigması ise Laugsch ve Spargo (1996)'nun ortaya koyduğu Fen-Teknoloji-Toplum ilişkisi ve Bilimin doğası konularını içeren ölçek ile Manhart (1997)'ın toplumsal perspektif, insan gayretiyle bilim ve günlük yaşamda fen bilimlerinin yeri konularını içeren ölçeğin birlikte harmanlanarak 21 . yüzyıl beceri ve yeterlilikleri ile zenginleştirilmesine dayanmaktadır. Bu kuramsal çerçeveye dayanan EFOYÖ, 4 boyut ve 8 faktör altında toplanmıştır. Bu boyut ve faktörlerin EFOYÖ'de hangi oranda ve kaç tane madde ile temsil edildiği ve ölçek boyutlarından alınabilecek en yüksek ve en düşük puanlara ilişkin bilgiler aşağıda yer alan Tablo 4'de gösterilmiştir.

\section{Tablo 4. EFOYÖ’yü oluşturan boyutlar ve faktörler}

\begin{tabular}{|c|c|c|c|c|}
\hline Boyutlar ve Faktörler & $\begin{array}{l}\text { Madde } \\
\text { Sayısı }\end{array}$ & $\begin{array}{l}\text { Yüzde } \\
(\%)\end{array}$ & $\begin{array}{c}\text { Alınabilecek } \\
\text { en yüksek } \\
\text { puan }\end{array}$ & $\begin{array}{l}\text { Alınabilecek } \\
\text { en düşük } \\
\text { puan }\end{array}$ \\
\hline Zihin Alışkanlığı & 13 & 27,1 & 65 & 13 \\
\hline Iletişsim ve iş birliği (F6) & 5 & 10,4 & & \\
\hline Sistematik düşünme/ Bilgi yönetimi (F3) & 8 & 16,7 & & \\
\hline Karakter ve Değerler & 9 & 18,7 & 45 & 9 \\
\hline $\begin{array}{l}\text { Ekolojik dünya görüşü/ Sosyal ve ahlaki } \\
\text { vicdan (F4) }\end{array}$ & 7 & 14,5 & & \\
\hline Sosyobilimsel sorumluluk (F7) & 2 & 4,2 & & \\
\hline İnsan Gayreti Olarak Bilim & 13 & 27,1 & 65 & 13 \\
\hline Fen ve toplum/Bilim ruhu (F1) & 10 & 20,8 & & \\
\hline Bilimsel bilginin karakteristiği (F8) & 3 & 6,3 & & \\
\hline
\end{tabular}




\begin{tabular}{|c|c|c|c|c|}
\hline Üst Biliş ve Özdenetim & 13 & 27,1 & 65 & 13 \\
\hline Planlama/denetleme (F2) & 10 & 20,8 & & \\
\hline Değerlendirme (F5) & 3 & 6,3 & & \\
\hline TOPLAM & 48 & 100 & & \\
\hline
\end{tabular}

EFOYÖ’nün, Zihin Alışkanlığl, Insan Gayreti Olarak Bilim ve Üst Biliş ve Özdenetim boyutları 13 madde ile; Karakter ve Değerler boyutu ise 9 madde ile temsil edilmektedir.

\section{Verilerin Analizi}

Verilerin normal dağılım gösterip göstermediği çarpıklık (-0.226; S:0.055)-basıklık (0.300; S:0.109) katsayısı ile test edilmiş, elde edilen değerlerin +1 ile -1 arasında olduğu belirlenmiştir. Bununla birlikte Q-Q plot grafiği, normal dağılımın bir göstergesi olarak dikkate alınmıştır. Bu iki göstergeye bakılarak verilerin normal dağılım gösterdiği söylenebilir. Verilerin normal dağılım gösterdiğine ilişkin sonuca bağlı olarak araştırmada, parametrik istatistik yöntemleri kullanılmıştır. Buna göre üniversitelerdeki fen bilgisi öğretmen adaylarının, evrensel fen okuryazarlığ boyutlarına ilişkin düzeyleri betimsel istatistik; cinsiyet ve sınıf düzeyi değişkenlerinin etkisi bağımsız gruplar t-testi; EFOYÖ düzeylerinin Türkiye İBBS'ye göre anlamlı farklılık gösterip göstermediği ise tek yönlü varyans analizi ile çözümlenmiştir. Örneklemin oldukça büyük olmasından dolayı analizlerin daha hassas yapılabilmesi için 0.01 anlamlılık düzeyi kullanılmıştır.

\section{Bulgular}

Bulgular bölümünde araştırma sorularına ilişkin bulgular, tablolar ve grafik halinde verilerek ayrı ayrı yorumlanmıştır. Verilerin analizi yapılırken, EFOYÖ’yü oluşturan boyutların aritmetik ortalaması dikkate alınmıştır. Bu durumun sebebi, farklı madde sayılarıyla temsil edilen boyutların birbirleriyle niceliksel olarak karşılaştırılmasının daha olanaklı olmasıdır.

\section{Evrensel Fen Okuryazarlığı Düzeyine İlişkin Bulgular}

Araştırmanın birinci alt problemi, fen bilgisi öğretmen adaylarının evrensel fen okuryazarlığı boyutlara göre hangi düzeydedir? sorusudur. Buna göre toplam 2008 fen bilgisi öğretmen adayının EFOYÖ'den aldığı ortalama puanlar ve standart sapma değerleri aşağıda yer alan Tablo 5'te verilmiştir.

Tablo 5. Öğretmen adaylarının EFOYÖ boyutlarına ilişkin betimsel istatistik sonuçları

\begin{tabular}{lcccc}
\hline & $\mathbf{N}$ & & $\bar{X}$ & $\mathbf{S}$ \\
\cline { 2 - 2 } Zihin Alışkanlığı & 2008 & & 4,05 & 0,40 \\
Karakter ve Değerler & 2008 & & 3,97 & 0,49 \\
İnsan Gayreti Olarak Bilim & 2008 & & 4,15 & 0,41 \\
Üst Biliş ve Özdenetim & 2008 & & 4,08 & 0,45 \\
\cline { 1 - 1 } \cline { 4 - 5 } EFOYÖ & 2008 & & 4,07 & 0,35 \\
\hline
\end{tabular}

Tablo 5'e göre fen bilgisi öğretmen adayları, zihin alışkanlığ boyutunun 4,05 $( \pm 0,40)$, karakter ve değerler boyutunun $3,98( \pm 0,49)$, bir insan gayreti olarak bilim boyutunun $4,16( \pm 0,41)$ ve üst biliş ve özdenetim boyutunun ise $4,09( \pm 0,46)$ puana sahip oldukları görülmektedir. EFOYÖ'yü oluşturan dört boyuta ilişkin ortalama değerler dikkate alındığında, fen bilgisi öğretmen adaylarının iyi düzeyde duyuşsal bir evrensel fen okuryazarı olduğu söylenebilir. Diğer bir ifade ile fen bilgisi öğretmen adaylarının, fen okuryazarı bir bireyde bulunması gereken duyuşsal özelliklere yeterli düzeyde sahip olduğu anlamına gelebilir. 


\section{Türkiye İstatistiki Bölge Birimlerine ilişkin Bulgular}

Araştırmanın ikinci alt problemi, fen bilgisi öğretmen adaylarının evrensel fen okuryazarlık düzeyi, farklı istatistiki bölge birimlerine göre nasıl bir farklılık gösterdiği sorusudur. Bu nedenden dolayı veriler üzerinde tek yönlü varyans analizi yapılmış ve elde edilen ANOVA bulguları Tablo 6 ve Tablo 7'de sunulmuştur.

Tablo 6. EFOYÖ boyutlarının Türkiye istatistiki bölge birimleri'ne göre betimsel istatistik sonuçları

\begin{tabular}{|c|c|c|c|c|}
\hline $\begin{array}{l}\text { İstatistiki } \\
\text { Bölgeler }\end{array}$ & $\begin{array}{c}\text { Zihin } \\
\text { alışkanlığı } \\
(\overline{\mathbf{x}} \pm \mathbf{S})\end{array}$ & $\begin{array}{c}\text { Karakter ve } \\
\text { Değerler } \\
(\overline{\mathbf{x}} \pm \mathbf{S})\end{array}$ & $\begin{array}{c}\text { İnsan Gayreti } \\
\text { olarak Bilim } \\
(\overline{\mathbf{x}} \pm \mathbf{S})\end{array}$ & $\begin{array}{c}\text { Üst Biliş ve } \\
\text { Özdenetim } \\
(\overline{\mathbf{x}} \pm S)\end{array}$ \\
\hline İstanbul & $4,07( \pm 0,36)$ & $4,05( \pm 0,46)$ & $\# 4,27( \pm 0,38)$ & $4,07( \pm 0,42)$ \\
\hline Batı Marmara & $* 3,93( \pm 0,45)$ & $3,90( \pm 0,47)$ & $4,05( \pm 0,39)$ & $4,01( \pm 0,44)$ \\
\hline Ege & $4,05( \pm 0,39)$ & $4,01( \pm 0,47)$ & $4,20( \pm 0,44)$ & $4,10( \pm 0,42)$ \\
\hline Doğu Marmara & $4,14( \pm 0,39)$ & $4,06( \pm 0,46)$ & $4,25( \pm 0,43)$ & $4,11( \pm 0,44)$ \\
\hline Batı Anadolu & $4,08( \pm 0,38)$ & $4,02( \pm 0,48)$ & $4,21( \pm 0,39)$ & $4,12( \pm 0,49)$ \\
\hline Akdeniz & $4,13( \pm 0,40)$ & $4,03( \pm 0,49)$ & $4,24( \pm 0,38)$ & $4,15( \pm 0,53)$ \\
\hline Orta Anadolu & $4,00( \pm 0,41)$ & $3,86( \pm 0,51)$ & $4,05( \pm 0,38)$ & $4,07( \pm 0,44)$ \\
\hline Batı Karadeniz & $3,97( \pm 0,45)$ & $* 3,84( \pm 0,52)$ & $* 3,99( \pm 0,41)$ & $* 3,95( \pm 0,47)$ \\
\hline D. Karadeniz & $3,96( \pm 0,38)$ & $3,95( \pm 0,48)$ & $4,14( \pm 0,39)$ & $4,08( \pm 0,40)$ \\
\hline Kuzeydoğu And. & $4,04( \pm 0,40)$ & $3,95( \pm 0,50)$ & $4,13( \pm 0,41)$ & $4,10( \pm 0,41)$ \\
\hline Ortadoğu And. & $\# 4,14( \pm 0,35)$ & $\# 4,07( \pm 0,45)$ & $4,22( \pm 0,35)$ & $\# 4,16( \pm 0,43)$ \\
\hline Güneydoğu And. & $4,04( \pm 0,31)$ & $3,95( \pm 0,43)$ & $4,08( \pm 0,30)$ & $4,08( \pm 0,49)$ \\
\hline Toplam & $4,05( \pm 0,40)$ & *3,97 $( \pm 0,49)$ & $\# 4,15( \pm 0,41)$ & $4,08( \pm 0,45)$ \\
\hline
\end{tabular}

Tablo 6'ya göre evrensel fen okuryazarlığını oluşturan dört boyutun aritmetik ortalamaları ve standart sapmaları sırasıyla şu şekildedir: zihin alışkanlı̆̆ $(4,05 \pm 0,40)$, karakter ve değerler $(3,97 \pm 0,49)$ bir insan gayreti olarak bilim $(4,15 \pm 0,41)$ üst biliş ve özdenetim $(4,08 \pm 0,35)$. Bu ortalama değerleri karşılaştırıldığında karakter ve değerler boyutu ortalamasının en düşük olduğu, üst biliş ve özdenetim boyutu ortalamasının ise en yüksek olduğu görülmektedir. Boyutlara ait ortalamalar bölgeler bazında karşılaştırıldığında, I. II. ve IV. boyuta ilişkin ortalamalar Ortadoğu Anadolu, III. boyuta ilişkin ortalama ise İstanbul bölgesinde en yüksektir. Öbür yandan I. boyuta ait ortalama Batı Marmara bölgesinde, II. III. ve IV. boyuta ilişkin ortalamalar Batı Karadeniz bölgesinde en düşüktür. Aşağıda bulunan Şekil 1, ortalamalara ait bu değerlerin bölgelere göre karşılaştırılmasını daha net bir biçimde ortaya koymaktadır. 


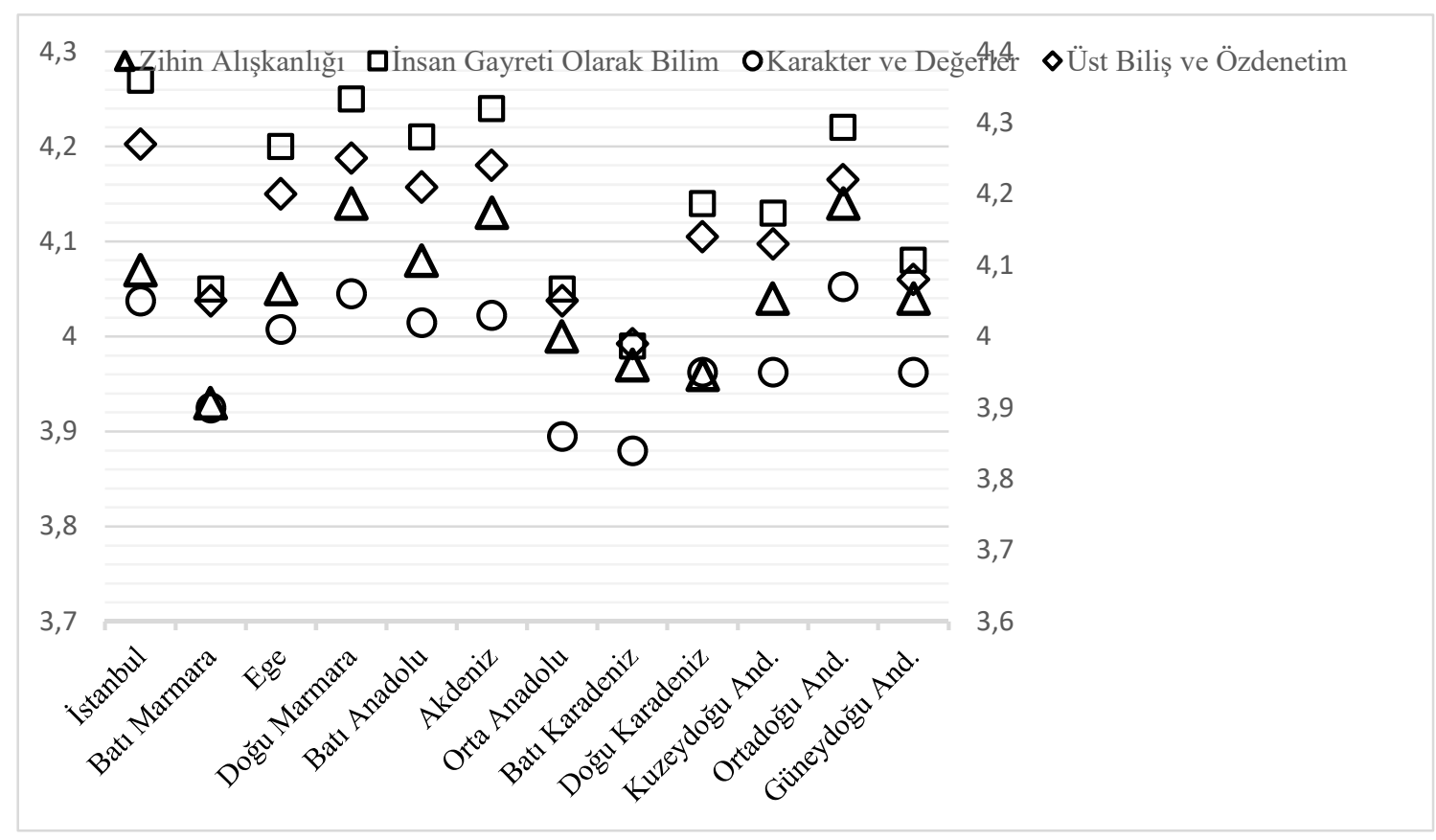

Şekil 1. EFOYÖ boyutlarının Türkiye İBBS'ye göre betimsel istatistik sonuçlarının grafikle gösterimi

Şekil 1'e göre 12 bölge arasında insan gayreti olarak bilim boyutu, diğer boyutların ortalamalarına göre genellikle daha yüksek düzeyde olduğu görülmektedir. Diğer taraftan ögrencilerin karakter ve değerler boyutuna ilişkin ortalamaları, her bölge için en düşük düzeyde olduğu sonucu ortaya çıkmıştır.

$\mathrm{Bu}$ bölgelerden araştırmaya katılan fen bilgisi öğretmen adaylarının evrensel fen okuryazarlığını oluşturan boyutlara ilişkin puan ortalamaları arasındaki farklılığın istatistiksel olarak anlamlı olup olmadığını tespit etmek amacıyla tek yönlü varyans analizi yapılmıştır. Buna ilişkin analiz sonuçları Tablo 7'de gösterilmiştir.

Tablo 7. Fen bilgisi öğretmen adaylarına ait EFOYÖ puanlarının İBBS'ye göre ANOVA sonuçları

\begin{tabular}{llcccccc}
\hline \multicolumn{1}{c}{ Boyutlar } & $\begin{array}{c}\text { Varyansın } \\
\text { Kaynağı }\end{array}$ & $\begin{array}{c}\text { Kareler } \\
\text { Toplamı }\end{array}$ & sd & $\begin{array}{c}\text { Kareler } \\
\text { Ortalaması }\end{array}$ & F & p & Anlamlı Fark \\
\hline \multirow{2}{*}{ Zihin } & Gruplar Arası & 1542.12 & 11 & 132.01 & 4.91 & 00 & $4-2,4-8,4-9$, \\
Alışkanlığı & Gruplar İçi & 53680.18 & 1996 & 26.89 & & & $6-2,6-8,6-9$, \\
& Toplam & 55132.30 & 2007 & & & & $11-2,11-8,11-9$ \\
\hline \multirow{2}{*}{ Karakter ve } & Gruplar Arası & 921.57 & 11 & 83.78 & 4.37 & 00 & $1-8,3-8,4-7$, \\
Değerler & Gruplar İçi & 38307.30 & 1996 & 19.19 & & & $4-8,5-8,6-7$, \\
& Toplam & 39228.87 & 2007 & & & & $6-8,11-7,11-8$ \\
\hline \multirow{2}{*}{ İnsan Gayreti } & Gruplar Arası & 2728.51 & 11 & 248.05 & 9.04 & 00 & $1-2,1-7,1-8,3-7,3-8,4-2$, \\
Olarak Bilim & Gruplar İçi & 54754.99 & 1996 & 27.43 & & & $4-7,4-8,5-7,5-8,6-2,6-7$, \\
& Toplam & 57483.50 & 2007 & & & & $6-8,9-8,11-7,11-8$ \\
\hline \multirow{2}{*}{ Üst biliş ve } & Gruplar Arası & 1095.05 & 11 & 99.55 & 2.81 & 00 & $4-8,5-8$, \\
Özdenetim & Gruplar İçi & 70672.91 & 1996 & 35.41 & & & $6-8,11-8$ \\
& Toplam & 71767.96 & 2007 & & & & \\
\hline
\end{tabular}


(1:İstanbul, 2: Batı Marmara, 3: Ege, 4: Doğu Marmara, 5: Batı Anadolu, 6: Akdeniz, 7: Orta Anadolu, 8: Batı Karadeniz, 9: Doğu Karadeniz, 10: Kuzeydoğu Anadolu, 11: Ortadoğu Anadolu, 12: Güneydoğu Anadolu)

Tablo 7'deki ANOVA sonuçlarından, fen bilgisi öğretmen adaylarının evren sel fen okuryazarlık düzeyi istatistiki bölge birimlerine göre anlamlı bir farklılık gösterdiği görülmektedir $\left[\mathrm{F}_{(11-1996)}=4.91, \mathrm{p}<.01\right] ;\left[\mathrm{F}_{(11-1996)}=4.37, \mathrm{p}<.01\right] ;\left[\mathrm{F}_{(11-1996)}=9.04, \mathrm{p}<.01\right] ;\left[\mathrm{F}_{(11-1996)}=2.81, \mathrm{p}<.01\right]$. Dolayısıyla öğretmen adaylarının fen okuryazarlık düzeyinde istatistiki bölge birimlerinin etkili bir faktör olduğu söylenebilir. Oluşan bu farklılığın hangi bölgeler arasında olduğunu tespit etmek amacıyla Scheffe testi yapılmıştır.

Buna göre Doğu Marmara, Akdeniz ve Ortadoğu Anadolu bölgelerindeki öğretmen adaylarının zihin alışkanlı̆̆ boyutunda evrensel fen okuryazarlık düzeyi, Batı Marmara, Batı Karadeniz ve Doğu Karadeniz bölgelerine göre daha yüksek olduğu tespit edilmiştir. Bunun yanında Doğu Marmara, Akdeniz ve Ortadoğu Anadolu bölgelerindeki öğretmen adaylarının Orta Anadolu bölgesindeki öğretmen adaylarına göre; İstanbul, Ege, Doğu Marmara, Batı Anadolu, Akdeniz ve Ortadoğu Anadolu bölgelerindeki öğretmen adaylarının ise Batı Karadeniz bölgesine göre karakter ve değerler boyutuna ilişkin fen okuryazarlık düzeyinin daha yüksek olduğu görülmektedir.

Diğer taraftan Batı Marmara bölgesindeki fen bilgisi öğretmen adaylarının evrensel fen okuryazarlık düzeyi insan gayreti olarak bilim boyutunda İstanbul, Doğu Marmara ve Akdeniz bölgelerindeki öğretmen adaylarına göre; Orta Anadolu bölgesindeki öğretmen adaylarının da İstanbul, Ege, Doğu Marmara, Batı Anadolu, Akdeniz ve Ortadoğu Anadolu bölgelerindeki öğretmen adaylarına göre daha düşük olduğu bulunmuştur. Bunun yanında Batı Karadeniz bölgesindeki öğretmen adaylarının ise evrensel fen okuryazarlık düzeyinin İstanbul, Ege, Doğu Marmara, Batı Anadolu, Akdeniz, Doğu Karadeniz ve Ortadoğu Anadolu bölgelerindeki öğretmen adaylarına göre düşük olduğu görülmüştür. Doğu Marmara, Batı Anadolu, Akdeniz ve Ortadoğu Anadolu bölgelerindeki öğretmen adaylarının evrensel fen okuryazarlık düzeyi üst biliş ve özdenetim boyutunda Batı Karadeniz bölgesindeki öğretmen adaylarına göre daha yüksek bulunmuştur.

\section{Cinsiyet Değişkenine İlişkin Bulgular}

Araştırmanın üçüncü alt problemiyle, fen bilgisi öğretmen adaylarının evrensel fen okuryazarlık düzeyi, cinsiyete göre nasıl farklılık göstermektedir? sorusuna cevap aranmıştır. Buna ilişkin olarak elde edilen veriler üzerinde bağımsız gruplar t-testi uygulanmış ve sonuçlar Tablo 8'de gösterilmiştir.

\section{Tablo 8. EFOYÖ boyutları puanlarının cinsiyete göre t-testi sonuçları}

\begin{tabular}{lccccccc}
\hline \multicolumn{1}{c}{ Boyutlar } & Cinsiyet & $\mathbf{N}$ & $\bar{X}$ & $\mathbf{S}$ & sd & t & p \\
\hline \multirow{2}{*}{ Zihin Alışkanlığı } & Kadın & 1564 & 4,06 & 0,39 & 2006 & 2,141 &, 032 \\
& Erkek & 444 & 4,01 & 0,43 & & & \\
Karakter ve & Kadın & 1564 & 4,00 & 0,48 & 2006 & 3,819 &, $000^{*}$ \\
Değerler & Erkek & 444 & 3,90 & 0,52 & & & \\
İnsan Gayreti & Kadın & 1564 & 4,18 & 0,40 & 2006 & 5,250 &, $000^{*}$
\end{tabular}


Olarak Bilim

Erkek

444

4,06

0,42

Üst Biliş ve

Kadın

1564

4,10

0,44

2006

2,705

, 012

Özdenetim

Erkek

4,03

0,51

${ }^{*} p<.01$ düzeyinde anlaml farklllık vardır.

Tablo 8'e göre fen bilgisi öğretmen adaylarının evrensel fen okuryazarlığını oluşturan Karakter ve Değerler ve İnsan Gayreti Olarak Bilim boyutlarında, cinsiyete göre anlamlı bir farklılık olduğu tespit edilmiştir. Bu boyutlara ilişkin puanlar, cinsiyet değişkenine göre istatistiksel olarak anlamlı bir farklılık oluşturmuştur $\left[\mathrm{t}_{(2006)}=3,819, \mathrm{p}<.01\right] ;\left[\mathrm{t}_{(2006)}=5,250, \mathrm{p}<.01\right]$. Meydana gelen bu farklılık kadın öğretmen adayları lehinedir. Bu bağlamda kadın öğretmen adaylarının, karakter ve değerler $(\overline{\mathrm{X}}=4,00)$ ile insan gayreti olarak bilim $(\overline{\mathrm{X}}=4,18)$ boyutlarına ilişkin puanları, erkek öğretmen adaylarına göre $(\bar{X}=3,90 ; \bar{X}=4,06)$ daha yüksektir. Diğer taraftan kadın ve erkeklerin Zihin Alışkanlı̆̆ ve Üst biliş ve Özdenetim boyutlarına ait puanları arasinda anlamlı bir farklılık bulunmamaktadır $\left[\mathrm{t}_{(2006)}=2,141, \mathrm{p}>.01\right] ;\left[\mathrm{t}_{(2006)}=2,705, \mathrm{p}>.01\right]$.

\section{Sınıf Düzeyine İlişkin Bulgular}

Araştırmanın dördüncü alt problemiyle, fen bilgisi öğretmen adaylarının evrensel fen okuryazarlığ sınıf düzeyine göre nasıl bir farklılık göstermektedir? sorusuna cevap aranmıştır. Bu amaçla eldeki veriler üzerinde bağımsız gruplar t-testi yapılmış ve ilgili bulgular Tablo 9'da verilmiştir.

Tablo 9. EFOYÖ boyutları puanlarının sınıf düzeyine göre t-testi sonuçları

\begin{tabular}{lccccccc}
\hline \multicolumn{1}{c}{ Boyutlar } & $\begin{array}{c}\text { Sinıf } \\
\text { Düzeyi }\end{array}$ & $\mathbf{N}$ & $\bar{X}$ & $\mathbf{S}$ & sd & $\mathbf{~ t}$ & $\mathbf{p}$ \\
\hline \multirow{2}{*}{ Zihin Alı̧̧kanlı̆ğ } & 1.Sınıf & 1088 & 4.04 & 0.42 & 2006 & -1.207 & .22 \\
& 4. Sınıf & 920 & 4.06 & 0.38 & & & \\
Karakter ve Değerler & 1.Sınıf & 1088 & 3.94 & 0.51 & 2006 & -2.925 & .00 \\
& 4. Sınıf & 920 & 4.01 & 0.46 & & & \\
İnsan Gayreti Olarak & 1.Sinıf & 1088 & 4.14 & 0.44 & 2006 & -1.427 & .15 \\
Bilim & 4. Sınıf & 920 & 4.17 & 0.37 & & & \\
Üst Biliş ve Özdenetim & 1.Sınıf & 1088 & 4.04 & 0.49 & 2006 & -4.451 & .00 \\
& 4. Sınıf & 920 & 4.13 & 0.41 & & & \\
\hline
\end{tabular}

Tablo 9'a göre fen bilgisi öğretmen adaylarının Evrensel Fen Okuryazarlı̆̆ı Ölçeğini oluşturan karakter ve değer ile üst biliş ve özdenetim boyutlarında sınıf düzeyine göre anlamlı farkl11ık gösterdiği görülmektedir $\left[\mathrm{t}_{(2006)}=-2,925, \mathrm{p}<.01\right] ;\left[\mathrm{t}_{(2006)}=-4,451, \mathrm{p}<.01\right]$. Bu bulgulara göre 4. sınıfların evrensel fen okuryazarlık düzeyi karakter ve değerler $(\overline{\mathrm{X}}=4,01)$ ile üst biliş ve özdenetim $(\overline{\mathrm{X}}=4,13)$ boyutlarında 1 . Sinıflara göre karakter ve değerler $(\overline{\mathrm{X}}=3,94)$ ve üst biliş ve özdenetim $(\overline{\mathrm{X}}=4,04)$ daha yüksektir. Ayrıca aşağıda EFOYÖ’yü oluşturan boyutların sınıf düzeyine göre betimsel istatistik sonuçlarına ilişkin grafik Şekil 2'de sunulmuştur. 


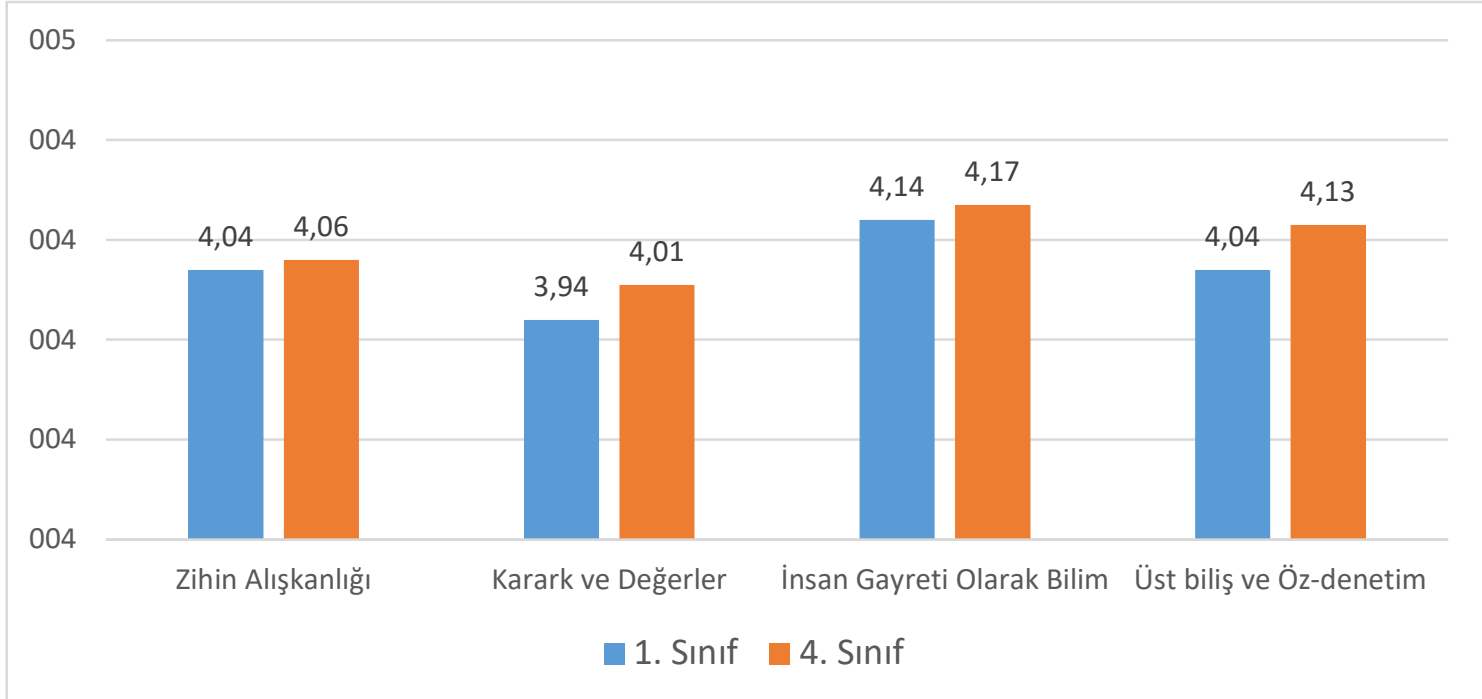

\section{Şekil 2. EFOYÖ boyutlarının sınıf düzeyine göre ortalamaları}

İletişim ve işbirliği ile sistematik düşünme/bilgi yönetimi duyuşsal özelliklerini ölçen zihin alışkanlı̆̆ boyutuyla, fen ve toplum/bilim ruhu ile bilimsel bilginin karakteristiği duyuşsal özelliklerini ölçen insan gayreti olarak bilim boyut puanlarında 1. sınıf ile 4. sınıf öğrencileri arasında kayda değer bir gelişim olmadığı görülmüştür. Ancak ekolojik dünya görüşü/sosyal ve ahlaki vicdan ile sosyobilimsel sorumluluk duyuşsal özelliklerini ölçen karakter ve değerler boyutuyla, planlama/denetleme ile değerlendirme duyuşsal özelliklerini ölçen Üst biliş ve Özdenetim boyutlarında 1. sınıf ile 4. sınıf öğrencileri arasında dikkate değer bir gelişim gösterdiği görülmektedir.

\section{Tartışma ve Sonuç}

Hem öğrencilerde hem de bireylerde fen okuryazarlığının oluşturulması için bilimsel bilgi ve beceri gereklidir; fakat tek başına yeterli değildir. Bu bilgi ve becerilerin bireyde özümsenebilmesi için fene özgü değerlerin ve bazı özelliklerinde kazandırılması oldukça önemlidir. Bu bakımdan EFOYÖ, salt bilişsel bilginin fen okuryazarlığını gösteren bir ölçüt olmayacağından hareketle, katılımcıların duyuşsal özelliklerini önemli bir etken olarak göz önüne almaktadır. Bu bağlamda elde edilen sonuçlar, öğretmen adaylarının fen okuryazarlığına yönelik duyuşsal yönlerini ortaya çıkarmaktadır. Bu bağlamda araştırma, Türkiye'nin farklı coğrafik bölgelerindeki farklı üniversitelerde öğrenim görmekte olan fen bilgisi öğretmen adaylarının evrensel fen okuryazarlığı düzeyini istatistiki bölge birimleri, cinsiyet, sınıf düzeyi değişkenlerine göre nasıl bir farklılık oluşturduğunu ortaya koymayı amaçlamıştır.

Fen okuryazarllğgn mevcut görüşlerinden birisi bireyin, fene karşı olumlu tutum ve ilgi geliştirmesi yönündedir (Hançer vd., 2003). Ancak fene yönelik olumlu tutum veya ilginin geliştirilmesi, evrensel bir bireyin yetiştirilmesi için tek başına yeterli olmayacağı düşünülmektedir. Çünkü tutumun ve motivasyonun ötesinde bireylerin, problemlerin çözümünde sorumluluk alma, çevre ve diğer insanlara saygılı olma, küresel konulara karşı duyarlı olma gibi yönleri de geliştirilmelidir (Hodson, 2003; Berkowitz ve Simmons, 2003). Bunun yanında, farklı değer ve kültürlere sahip olan bireylere saygıl1, kendisi dışındaki varlıklara karşı merhametli olan ve daha fazla refah için sosyobilimsel sorumluluğa sahip bireylerin yetiştirilmesi oldukça önemlidir (Mun, Shin vd., 2015). Bu araştırmada fen bilgisi öğretmen adaylarının evrensel fen okuryazarlık boyutlarından karakter ve değerler boyutu orta; diğer boyutlara ilişkin düzeyleri ise yüksek olduğu söylenebilir. Bu 
durum, öğretmen adaylarının genel anlamda yüksek düzeyde duyuşsal özelliklere sahip bir evrensel fen okuryazarı olduğunu göstermektedir. Chin (2005) Tayvan'da sınıf ve fen bilimleri öğretmen adaylarının temel fen okuryazarlık düzeylerini bilimin doğası, fen-teknoloji-toplum ve içerik bilgisi kapsamında tatmin edici seviyede olduğu sonucuna ulaşmıştır. $\mathrm{Bu}$ sonuç araştırma bulgusunu destekler niteliktedir. Alan yazında farklı sonuçların elde edildiği çalışmalara da rastlamak mümkündür. Nitekim fen bilgisi öğretmen adaylarının fen okuryazarlık düzeyinin orta seviyede olduğuna yönelik çalışmalar lireratürde yer almaktadır (Bacanak, 2002; Ulutaş, 2009). Özdemir (2010), öğretmen adaylarının, fen okuryazarlık düzeyinin orta seviyede çıkmasını fen ile ilgili anahtar kavramların yeterince bilinememesi, bilimin doğasının özümsenememesi ve bilimsel gelişmeleri yeterince takip edememesine dayandırmıştır. Diğer taraftan sınıf öğretmen adayları üzerinde gerçekleşen araştırmada, öğretmen adaylarının fen okuryazarlık düzeyinin düşük olduğu sonucu, mevcut araştırma bulgularından farklılık göstermektedir (Huyugüzel Çavaş, 2009).

Fen bilgisi öğretmen adaylarının, karakter ve değerler boyutuna ilişkin düzeyi, diğerlerine göre daha düşük, bir insan gayreti olarak bilim boyutuna ilişkin düzeyi ise daha yüksek bulunmuştur. Daha derinlemesine irdelenecek olursa öğretmen adaylarında, karar verme, seçim yapma ve problem çözme sürecinde bilimsel bilginin etkili kullanılması gibi yönlerinin daha gelişmiş olduğu; ekolojik dünya görüşü/sosyal ve ahlaki vicdan ve sosyobilimsel sorumluluk gibi yönlerinin ise daha zayıf olduğu ortaya çıkmıştır. Chin'in (2005) bilimin doğası ve fen-teknolojitoplum boyutları için öğretmen adaylarının fen okuryazarlık düzeyini yüksek bulduğu çalışması, bu araştırmada elde edilen fen ve toplum/bilimsel bilgisinin karakteristiği konusunda evrensel fen okuryazarlık düzeyinin yüksek olması açısından araştırma bulgularıyla benzerlik göstermektedir. Çepni ve diğerleri (2012), fen okuryazarlığının öğrenciye kazandırılmasında etkili yaklaşımlardan birisinin fen-teknoloji ve toplum olduğunu belirtmiştir. Nitekim 2005 yılında değişen fen bilimleri öğretim programında yer alan Fen-Teknoloji-Toplum-Çevre boyutu, fen okuryazarı bireylerin yetişmesinde fen eğitiminin önemli bir parçası haline gelmiştir. Bu araştırma sonucundan hareketle fen bilgisi öğretmen adaylarının, sosyal ve çevresel ihtiyaçların bilim ve teknolojiyi şekillendirdiği, bilimsel ve teknolojik ürünlerin de insanların yaşama şartlarını, toplumların yapısını ve çevreyi etkilediği görüşünü benimsediği ifade edilebilir.

Karakter ve Değerler boyutu altında yer alan ekolojk dünya görüşlerinin orta düzeyde olduğu sonucuna ulaşılmıştır. Akçay ve Pekel'in (2017) eğitim fakültesinin çeşitli bölümlerindeki öğretmen adaylarının çevre bilinci ve çevre duyarlılığ düzeylerine ilişkin yaptığ çalışmada fen bilgisi öğretmen adaylarının çevre bilinci ve çevre duyarlılığının orta düzeyde olduğu sonucuna ulaşmıştır. Bu sonuç mevcut araştırma sonucuyla paralellik göstermektedir. Aynı araştırmada sosyoloji, biyoloji ve coğrafya bölümlerindeki ögretmen adaylarının çevre duyarlılıkları ise fen bilgisi ile birlikte farklı bilim dallarına göre daha yüksek çıkmıştır. Fen bilgisi öğretmen adaylarının lisans öğrenimlerinde; çevre bilimi ve yer bilimi derslerini kapsayan bazı coğrafya dersleriyle beraber insanoğlunun içinde yaşadığı canlılar ile ilişkisini açıklayan biyoloji dersini almaları sebebiyle çevre bilinci ve çevre duyarlılıklarının daha yüksek olması beklenirken, farklı bir sonucun ortaya çıkmasının oldukça şaşırtıcı olduğu düşünülmektedir. Dolayısıyla öğretmen adaylarının ekolojik dünya görüşlerini geliştirmede empati duygularını da harekete geçirecek doğa ile etkileşimli öğrenme ortamlarının yaratılması faydalı olabilir. Buna karşın, Teksöz, Şahin, Ertepınar (2010), öğretmen adaylarının çevre ile ilgili farkındalıkları ve çevreye ilişkin kişisel sorumlulukları ile ilgili maddelere yüksek oranda olumlu görüşler belirttiğini ifade etmiştir.

Karakter ve Değerler boyutu altında yer alan sosyobilimsel sorumluluklarının orta düzeyde olduğu ortaya çıkmıştır. Sosyobilimsel konuların eğitimi, sosyobilimsel problemlere çözüm getirmek için verilecek kararın sorumluluğu fen okuryazarlığının önemli bir parçasıdır. Dawson, (2011), 
bireyleri çağdaş toplumların evrensel bir vatandaşı haline getirmesinde sosyobilimsel konuların önemli katkısı olduğunu belirtmiştir. Çünkü sosyobilimsel konuları merkeze alarak yürütülen fen eğitimi, başta bireyin çevresinde yaşanan problemleri tespit etmesine ve bu problemlere çözüm üretmeye yönelik karar verme becerilerini geliştirmesine yardımcı olmaktadır. $\mathrm{Bu}$ süreçte ise öğrencilerin fen kavramlarını daha iyi anladığı, öğrenmeye karşı daha istekli ve ilgili olduğu, fene yönelik tutumlarına pozitif katkı sağladığı tespit edilmiştir (Topçu, Muğaloğlu ve Güven, 2014). Ancak hem karakter ve değerler boyutuna ilişkin araştırma sonuçları, hem de alan yazında ortaya çıkan diğer sonuçlar (Demirkaya, 2006; Boerwinkel, Knippels ve Warloo 2011; Topçu, Muğaloğlu ve Güven, 2014; Akçay ve Pekel, 2017 ) bireylerin sosyobilimsel konulara ilişkin karar verme becerilerini kullanmaya yeteri kadar yetkin olmadığı ve çevreye yönelik bilinçlerinde de eksiklikler olduğunu göstermiştir. Bu bakımdan literatürde elde edilen sonuçlar, gerek ekolojik dünya görüşü gerekse sosyobilimsel sorumluluk açısından araştırma sonuçlarıyla uyumlu olduğu görülmektedir.

Türkiye İstatistiki Bölge Birimleri bağlamında ele alınırsa Batı Marmara, Orta Anadolu ve Batı Karadeniz bölgelerinde öğrenim gören fen bilgisi öğretmen adaylarının evrensel fen okuryazarlık düzeyi ölçeğin tüm boyutlarında genellikle düşük olduğu görülmüştür. Dolayısıyla bu bölgelerdeki öğrencilerin iletişim ve işbirliği, sistematik düşünme, ekolojik dünya görüşü, sosyobilimsel sorumluluk, fen ve toplum ilişkisi, duygu, düşünce ve davranışlarını kontrol edebilme becerisi olarak tanımlanan özdenetim, öğrenme stratejilerinin ve kendi zihinsel faaliyetlerinin farkındalığı (üst biliş) diğer bölgelere göre yeterli beceriye sahip olmadıkları söylenebilir. Diğer taraftan Doğu Marmara, Akdeniz ve Ortadoğu Anadolu bölgelerindeki öğretmen adaylarının evrensel fen okuryazarlık düzeyi ölçeğin tüm boyutlarında genellikle yüksek çıkmıştır. Bu bölgelerde öğrenim gören fen bilgisi öğretmen adaylarının öğrenim gördükleri üniversitelerin, kendilerini fen okuryazarlığı yönünden geliştirdiği düşünülmektedir.

Araştırmada bir diğer sonuca göre fen bilgisi öğretmen adaylarının evrensel fen okuryazarlığı düzeyine cinsiyetin etkisi bulunmuştur. Buna göre cinsiyet değişkeni, karakter ve değerler ile insan gayreti olarak bilim boyutlarında kadın öğretmen adayları lehine etkili olduğu ortaya çıkmıştır. Bu bağlamda kadın fen bilgisi öğretmen adaylarının, erkeklere göre ekolojik dünya görüşü, sosyobilimsel sorumluluk, fen ve toplum, bilimsel bilginin karakteri anlayışlarının daha fazla gelişmiş olduğu söylenebilir. Literatürde benzer sonuçların elde edildiği araştırmalara rastlamak mümkündür. Özdemir (2010), fen okuryazarlığı düzeyinin kadın öğretmen adaylarında daha yüksek olduğu sonucuna ulaşmış, bunun sebebini ise kadın öğretmen adaylarının fen derslerine yönelik ilgi ve meraklarının erkek öğretmen adaylarına göre daha fazla olmasına bağlamıştır. Mun ve diğerleri (2013) tarafından Evrensel Fen Okuryazarlığı Ölçeğini kullanarak, Avusturalya ( $n=198)$, Çin $(\mathrm{n}=230)$ ve Güney Kore'den $(\mathrm{n}=218)$ toplam 646 öğrenci üzerinde bir çalışma gerçekleştirilmiştir. Elde edilen bulgular, kadın öğrencilerin eleştiri kabul etme, grubun hedeflerini dikkate alma, ve doğaya ve insanlara karşı empati kurma gibi fen okuryazarlığın karakteristik özelliklerini, erkek öğrencilere göre daha fazla olduğunu göstermiştir. Yine Mun ve diğerleri (2015), evrensel fen okuryazarlık ölçeğini kullanarak Güney Kore'de 7. sınıftan 12. sınıfa kadar toplam 3.202 öğrenci üzerinde gerçekleştirdiği bir başka araştırmada kadın öğrencilerin, insan gayreti olarak bilim ve karakter ve değer boyutlarına ilişkin düzeyleri, erkek öğrencilere göre daha yüksektir. Bu sonuç, mevcut araştırmanın bulguları ile örtüşmektedir. Bir başka araştırmada Ulutaş (2009), fen bilgisi öğretmen adaylarının fen okuryazarlık düzeyini araştırdığı yüksek lisans tezinde, kadın öğretmen adaylarının erkek öğretmen adaylarından daha yüksek düzeyde fen okuryazarı olduğunu belirtmiştir. Ulusal çapta yapılan bu çalışmaların sonucunda getirilen önerilerde, örneklemin daha fazla genişletilmesinin daha sağlıklı bir yorum yapılabilmesi açısından önemli olduğu belirtilmiştir. Bu doğrultuda, 2008 örneklem üzerinde uygulanan ve lisans öğrencilerinin fen okuryazarlık düzeyini 
daha geniş kapsamlı şekilde ölçen mevcut araştırmada cinsiyet değişkeninin kadın öğretmen adayları lehine bir farklılık gösterdiği sonucuna ulaşılmıştır. Gerek yukarıda bahsedilen çalışmaların sonuçları, gerekse Jenkins ve Nelson (2005) ve Denizoğulu (2008)'nun ulaştı̆̆ sonuçlar araştırma bulgularını destekler niteliktedir. Bunun yanında farklı sonuçların elde edildiği çalışmalar da mevcuttur (Huyugüzel Çavaş, 2009 ve Yetişir, 2007). Ayrıca Bacanak ve Gökdere (2009), Chin (2005) ve Miller (2002) erkek öğretmen adaylarının kadın öğretmen adaylarından daha yüksek fen okuryazarlık düzeyine sahip olduğu sonucuna ulaşmışlardır.

Araştırmanın son bulgusuna göre fen bilgisi öğretmen adaylarının fen okuryazarlık düzeyine sınıf düzeyinin, karakter ve değerler ile üst biliş ve özdenetim boyutlarında etki ettiği; bu etkininde 4. sınıfların lehine olduğu tespit edilmiştir. Bu sonuç 2013 ve 2018 Fen Bilimleri Öğretim Programı açısından oldukça umut verici bir durumdur. Çünkü 2002 ve 2006 yıllarında gerçekleşen PISA'nın fen okuryazarlık sonuçlarına göre ülkemiz, yaklaşık 50 katılımcı ülke arasından son sıralarda yerini almıştır (EARGED, 2007; OECD, 2004). Bu sebeple mevcut öğrencilerin fen okuryazarı bireyler olarak yetiştirilmesinin arkasında kaliteli ve nitelikli bir eğitim yatmaktadır. Dolayısıyla fen okuryazarı bireyin yetiştirilmesinde en önemli etmenlerden birisi fen bilgisi öğretmenlerinin fen okuryazarı bireyler olmasıdır (Doğan ve Yılmaz, 2013; Özdem vd, 2010). Türkiye'nin mevcut 4. sınıf fen bilgisi öğretmeni adaylarının, eğitiminin ilk yıllarından itibaren yapılandırmacı öğrenme yaklaşımına göre öğrenim gördüğü bilinmektedir. Dolayısıyla, temelleri 2004 yılında Fen ve Teknoloji Öğretim Programıyla atılan ve mevcut Fen Bilimleri Öğretim Programıla sürdürülen fen okuryazarı bireylerin yetiştirilmesi amacını, araştırmadan elde edilen bulgular da desteklemektedir. Doğan ve Yılmaz (2013), 14 farklı ilden 70 farklı okulda fen bilimleri öğretmenliği yapan toplam 297 öğretmen üzerinde uyguladığı nitel bir araştırmada, yapılandırmacı yaklaşımın öğrencinin fen okuryazarı olarak yetişmesindeki etkisini incelenmiştir. Elde edilen bulgulara göre öğretmenlerin \%70 ( $\mathrm{N}=192)$ 'i yapılandırmacı yaklaşıma göre şekillenen fen ve teknoloji öğretim programının, öğrencileri fen okuryazarı yapma yönünden olumlu ve yeterli bulmuştur. Bunun yanında Kaya ve Bacanak (2013), nitel araştırma yöntemlerinden görüşme tekniğiyle yürütülen araştırmada, fen bilgisi öğretmen adaylarının, kendilerini fen okuryazarlığı yönünden oldukça yeterli gördüğü sonucuna ulaşmıştır.

\section{Öneriler}

Tüm bulgular bütünsel olarak göz önünde bulundurulduğunda şu öneriler getirilebilir:

- Fen bilgisi öğretmen adaylarının karakter ve değerler boyutu altında ekolojik dünya görüşünü geliştirmek amacıyla, çevre eğitimi derslerinin disiplinler arası bir yaklaşımla (biyoloji, sosyoloji ve coğrafya) yürütülmesi sağlanabilir.

- Fen bilgisi öğretmen adaylarının karakter ve değerler boyutu altında sosyobilimsel sorumluluk davranışlarını daha fazla geliştirmek amacıyla, fen bilgisi öğretmenliği programında seçmeli dersler açılabilir ya da mevcut olan derslerin içeriğine, kazandırılması beklenen özelliklere ilişkin etkinlikler eklenebilir.

- Bilimsel araştırma projeleri biriminin desteklediği bu araştırma, nicel yaklaşım kullanılarak yürütülmüştür. Ancak araştırmada istatistiki bölge birimlerinin, öğrencilerin evrensel fen okuryazarlık düzeyini farklılaştırma nedenlerini ortaya çıkaracak nitel araştırma yöntemlerinden faydalanılabilir. 
Fen Bilgisi Öğretmen Adaylarının Türkiye İstatistiki Bölge Birimlerine Göre Evrensel Fen Okuryazarlık Düzeyi başlıklı çalışmanın yazım sürecinde bilimsel, etik ve alıntı kurallarına uyulmuş; toplanan veriler üzerinde herhangi bir tahrifat yapılmamış, karşılaşılacak tüm etik ihlallerde "Pamukkale Üniversitesi Eğitim Fakültesi Dergisi Yayın Kurulunun" hiçbir sorumluluğunun olmadığı, tüm sorumluluğun Sorumlu Yazara ait olduğu ve bu çalışmanın herhangi başka bir akademik yayın ortamına değerlendirme için gönderilmemiş olduğunu taahhüt ederim. 


\section{Kaynakça}

Akçay, S. ve Pekel, F. O. (2017). Öğretmen adaylarının çevre bilinci ve çevresel duyarlılıklarının çeşitli değişkenler açısından incelenmesi. Elementary Education Online, 16(3), 1174-1184.

Anagün, Ş. S. (2011). PISA 2006 sonuçlarına göre öğretme-öğrenme süreci değişkenlerinin öğrencilerin fen okuryazarlıklarına etkisi. Ĕgitim ve Bilim, 36(162), 84-102.

Bacanak, A. (2002). Fen bilgisi ögretmen adaylarının fen okuryazarlıkları ile fen-teknoloji-toplum dersinin uygulanışını değerlendirmeye yönelik bir çalışma. Yayınlanmamış Yüksek Lisans Tezi, Karadeniz Teknik Üniversitesi, Trabzon.

Bacanak, A. ve Gökdere, M. (2009). Investigating level of the scientific literacy of primary school teacher candidates. Asia-Pacific Forum on Science Learning and Teaching, 10(1), 1-10.

Balkan Kıyıcı, F., Atabek Yiğit, E. ve Darçın, E. S. (2014). Doğa Eğitimi ile öğretmen adaylarının çevre okuryazarlık düzeylerindeki değişimin ve görüşlerinin incelenmesi. Trakya Üniversitesi Eğitim Fakültesi Dergisi, 4(1), 17-27.

Başaran, M. (2005). sınıf öğretmeni adaylarının bilgi okuryazarlıklarının değerlendirilmesi. Gazi Üniversitesi Gazi Eğitim Fakültesi Dergisi, 25(3), 163-177.

Berkowitz, M. W. ve Simmons, P. (2003). Integrating science education and character education. In D. L. Zeidler (Ed.), The Role of Moral Reasoning on Socioscientific İssuesaAnd Discourse in Science Education (s. 117-138). Dordrecht: Kluwer Academic Publishers.

Boerwinkel, D.J., Knippels, M.J., \& Waarlo, A.J. (2011). Raising awareness of presymptomatic genetic testing. Journal of Biological Education, 45(4), 213-221.

Bora, N. D., Aslan, O. ve Çakıroğlu, J. (2006). Lise öğrencilerinin bilim ve bilim insanı hakkındaki görüşleri. Hacettepe Üniversitesi Eğitim Fakültesi Dergisi, 31, 32-44.

BouJaoude, S. (2002). Balance of scientific literacy themes in science curricula: the case of lebanon. International Journal of Science Education, 24(2), 139-156.

Can, Ş. (2007). Fen bilgisi öğretmenliği öğretmen adaylarının fen okuryazarlık düzeyleri üzerine bir çalışma. 21. Ulusal Kimya Kongresi konferansı, 23-27 Ağustos 2007, Malatya.

Can, Ş. ve Öner, E. (2008). Sınıf Öğretmenliği Öğretmen Adaylarının Fen Okuryazarlık Düzeylerinin, Bazı Değişkenler Açısından Değerlendirilmesi, VII. Ulusal Sinıf Öğretmenliği Eğitimi Sempozyumu, 2-4 Mayıs 2007, Çanakkale, 794-797.

Canbaz, N. (2010). Yetişkin ĕgitimi kurslarına devam eden kadın kursiyerlerin teknoloji okuryazarlı̆̆ e ĕitim ihtiyacını belirleme. Yayınlanmamış Yüksek Lisans Tezi, Çanakkale On Sekiz Mart Üniversitesi, Çanakkale.

Chin, C. C. (2005). First year preservice teachers in taiwan-do they enter the teacher program with satisfactory scientific literacy and attitudes toward science? International Journal of Science Education, 27(13), 1549-1570.

Choi, K., Lee, H., Kim, S.W. \& Krajcik, J. (2011). Re-conceptualization of scientific literacy in south korea for the 21st century. Journal of Research in Science Teaching, 48(6), 670-697.

Creswell, J. W. \& Plano Clark, V. L. (2015). Karna Yöntem Araştırmaları Tasarımı ve Yürütülmesi. (Y. Dede ve S. B. Demir, Çev.). Ankara: Anı Yayıncılık.

Çelik, C. ve Can, Ş. (2017). Intercultural adaptation and validity study: universal science literacy scale (USLS). Universal Journal of Educational Research 5(12), 2125-2136.

Çepni, S., Ayvacı, H. Ş. ve Bacanak, A. (2012). Bilim teknoloji toplum ve sosyal değişim (5. Baskı). Trabzon: Celepler Matbaacilik.

Çoklar, A. N. ve Şahin, Y. L. (2014). Öğrencilerin gözüyle teknoloji okuryazarlığı: nedir, neredeyiz, aile ve çocuklar için neler yapmalı? Turkish Online Journal of Qualitative Inquiry, 5(2), 27-34.

Dani, D. (2009). Scientific literacy and purposes for teaching science: a case study of lebanese private school teachers. International Journal of Environmental \& Science Education, 4(3), 289-299.

Dawson, V. M. (2011). A case study of the impact of introducing socio-scientific issues into a reproduction unit in a catholic girls' school. T. D. Sadler (Eds.). Socio-scientific issues in the classroom (pp. 313345). New York: Springer Dordect. 
DeBoer, G. E. (2000). Scientific literacy: another look at its historical and contemporary meanings and its relationships to science education reform. Journal of Research in Science Teaching, 37(6), 583-599.

Demirkaya, H. (2006). Çevre eğitiminin Türkiye'deki coğrafya programları içerisindeki yeri ve çevre eğitimine yönelik yeni yaklaşımlar. Fırat Üniversitesi Sosyal Bilimler Dergisi, 16(1), 207-222.

Doğan, N., Çakıroğlu, J., Bilican, K. ve Çavuş, S. (2012). Bilimin Doğası ve Öğretimi. Ankara: Pegem Yayıncilik.

Doğan, Y. ve Yılmaz, M. (2013). Yapılandırmacı programın öğrencileri fen ve teknoloji okuryazarı yapma rolü ve programın uygulanmasına ilişkin öğretmen görüşlerinin incelenmesi. Journal of Mustafa Kemal University Graduate School of Social Sciences, 10 (23), 119-129.

Duban, N. (2010). Sınıf öğretmeni adaylarının fen ve teknoloji okuryazarı bireylere ve bu bireylerin yetiştirilmesine ilişkin görüşleri. Kuramsal Eğitim Bilim Dergisi, 3(2), 162-174.

Duran, M. ve Bekdemir M. (2013). Görsel matematik okuryazarlı̆̆ı özyeterlik algısıyla görsel matematik başarısının değerlendirilmesi. Pegem Journal of Education \& Instruction/Pegem Eğitim ve Öğretim Dergisi, 3(3), 27-40.

Duruk, Ü. (2012). İlköğretim ikinci kademe ögrrencilerinin fen ve teknoloji okuryazarllğg seviyesinin belirlenmesi. Yayınlanmamış Yüksek Lisans Tezi, Kocaeli Üniversitesi, Kocaeli.

EARGED (2007). PISA 2006 uluslararası öğrenci değerlendirme programı ulusal ön rapor. Ankara: MEB Eğitimi Araştırma ve Geliştirme Dairesi Başkanlığı.

Erdoğan, M. N. ve Köseoğlu, F. (2012). Ortaöğretim fizik, kimya ve biyoloji dersi öğretim programlarının bilimsel okuryazarlık temaları yönünden analizi. Educational Sciences: Theory \& Practice, 12(4), 2889-2904

Fives, H., Huebner, W., Birnbaum, A. S. \& Nicolich, M. (2014). Developing a measure of scientific literacy for middle school students. Science Education, 98(4), 549-580.

Foster, J. S. \& Shiel-Rolle, N. (2011). Building scientific literacy through summer science camps: a strategy for design, implementation and assessment. Science Education International, 22(2), 85-98.

Glynn, S. M. \& Koballa, T. R. (2006). Motivation to learn college science. Mintzes, J.J. ve William, H. L. (Ed.), Handbook of college science teaching. Arlington VA: National Science Teachers Association Press.

Hançer, A. H., Şensoy, Ö. ve Yıldırım, H. İ. (2003). İlköğretimde çağdaş fen bilgisi öğretiminin önemi ve nasıl olması gerektiği üzerine bir değerlendirme. Pamukkale Üniversitesi Eğitim Fakültesi Dergisi, 1(13), 8088.

Hodson, D. (2003). Time for action: science education for an alternative future. International Journal of Science Education, 25(6), 645-670.

Hurd, P. D. (1998). Scientific literacy: new minds for a changing world. Science Education, 82(3), 407-416.

Huyugüzel Çavaş, P. (2009). Sinı öğretmenlerinin fen ve teknoloji okuryazarlıklart ile öğretim yeterliklerinin belirlenmesi. Yayınlanmamış Doktora Tezi, Dokuz Eylül Üniversitesi, İzmir.

Jenkins, E. W. \& Nelson, N. W. (2005). İmportant but not for me: students' attitudes towards secondary school science in England. Research in Science \& Technological Education, 23(1), 41-57.

Karatekin, K. ve Aksoy, B. (2012). Sosyal bilgiler öğretmen adaylarının çevre okuryazarlık düzeylerinin çeşitli değişkenler açısından incelenmesi. Turkish Studies, 7(1), 1423-1438.

Kaya, M. ve Bacanak, A. (2013). Fen ve teknoloji öğretmen adaylarının düşünceleri: fen okuryazarı birey yetiştirmede öğretmenin yeri. Dicle University Journal of Ziya Gökalp Education Faculty, 21, 209-228.

Kılıç Bağc1, G., Haymana, F. ve Bozyılmaz, B. (2008). İlköğretim fen ve teknoloji dersi öğretim programı'nın bilim okuryazarlığı ve bilimsel süreç becerileri açısından analizi. Eğitim ve Bilim, 33(150), $52-63$.

Kurbanoğlu, S. ve Akkoyunlu, B. (2001). Öğrencilere bilgi okuryazarlı̆̆ becerilerinin kazandırılması üzerine bir çalışma. Hacettepe Üniversitesi Ĕ̈itim Fakültesi Dergisi, 21, 81-88.

Laugksch, R. C. (2000). Scientific literacy: a conceptual overview. Science Education, 84(1), 71-94.

Laugksch, R. C. \& Spargo, P. E. (1996). Construction of a paper-and-pencil test of basic scientific literacy based on selected literacy goals recommended by the American association for the advancement of science. Public Understanding of Science, 5(4), 331-359. 
Lederman, N. G., Antink, A. \& Bartos, S. (2014). Nature of science, scientific inquiry, and socio-scientific issues arising from genetics: a pathway to developing a scientifically literate citizenry. Science and Education, 23, 285-302.

Liu, X. (2009). Beyond science literacy: science and the public. International Journal of Environmental \& Science Education, 4(3), 301-311.

Manhart, J. J. (1997). Scientific literacy: factor structure and gender differences. Yayınlanmamış Doktora Tezi, Graduate College of The University of Iowa, Canada.

Millar R. \& Osborne, J. (1998). Beyond 2000: Science education for the future. London, UK: King's College.

Miller, J. D. (1983). Scientific literacy: A conceptual and empirical review. Daedalus Online, 112(2), 29-48.

Miller, J. D. (1998). The measurement of civic scientific literacy. Public Understanding of Science, 7(3), 203223.

Miller, J. D. (2002). Civic scientific literacy: a necessity in the 21 st century. FAS Public Interest Reports, 55(1), 3-6.

Mun, K., Lee, H., Kim, S.W., Choi, K., Choi, S.Y. \& Krajcik, J.S. (2013). Cross-cultural comparison of perceptions on the global scientific literacy with Australian, Chinese, and Korean middle school students. International Journal of Science and Mathematics Education, 13(2), 437-465.

Mun, K., Shin, N., Lee, H., Kim, S. W., Choi, K., Choi, S. Y. \& Krajcik, J. S. (2015). Korean secondary students' perception of scientific literacy as global citizens: Using global scientific literacy questionnaire. International Journal of Science Education, 37( 11), 1739-1766.

National Research Council [NRC] (1996). National science education standards. Washington, DC: National Academy Press.

Norris, S. P. \& Phillips, L. M. (2003). How literacy in its fundamental sense is central to scientific literacy. Science Education, 87(2), 224-240.

OECD, (2004). Learning for tomorrow's world. first results from PISA 2003. Paris: Programme for International Student Assessment.

Özdem, Y., Çavaş, P., Çavaş, B., Çakıroğlu, J. ve Ertepınar, H. (2010). An investıgation of elementary students' scientific literacy levels. Journal of Baltic Science Education, 9(1), 6-19.

Özdemir, O. (2010). Fen ve teknoloji öğretmen adaylarının fen okuryazarlığının durumu. Türk Fen Ĕ̆itim Dergisi, 7(3). 42-56.

Özmusul, M. (2012). Upper primary school students' views towards scientific knowledge: An analysis for information literacy. Ilkögretim Online, 11(3), 629-645.

Özsoy Güneş, Z., Çıngıl Barış, Ç. ve Kırbaşlar, F. G. (2013). Fen bilgisi öğretmen adaylarının matematik okuryazarlığı öz-yeterlik düzeyleri ile eleştirel düşünme eğilimleri arasındaki ilişki. Journal of Hasan Ali Yücel Faculty of Education / Hasan Ali Yücel Eğitim Fakültesi Dergisi, 10(1) 47-64.

Rodrigues, A. \& Oliviera, M. (2008). The influence of pupils' proficiency in the official school language in the assessment of scientific literacy, European Educational Research Association Conference, 10 - 12 September 2008, Sweden.

Sarıbaş, D. (2015). Investigating the relationship between pre-service teachers' scientific literacy, environmental literacy and life-long learning tendency. Science Education International, 26(1), 80-100.

Shamos, M.H. (1995). The myth of scientific literacy, New Brunswick-New Jersey: Rutgers University Press.

Topçu, M. S., Muğaloğlu, E. Z. ve Güven, D. (2014). Fen eğitiminde sosyobilimsel konular: Türkiye örneği. Kuram ve Uygulamada Ĕ̈itim Bilimleri Dergisi, 14(6), 2327-2348.

Topdemir, H.G. ve Ünat, Y. (2013). Bilim Tarihi. Ankara: Pegem Akademi.

Tunç Şahin, C. ve Say, Ö. (2010). İlköğretim öğrencilerinin bilimsel okuryazarlık düzeylerinin incelenmesi. Zonguldak Karaelmas Üniversitesi Sosyal Bilimler Dergisi, 6(11), 223-240.

Turgut, H. (2007). Herkes için bilimsel okuryazarlık. Ankara University Journal of Faculty of Educational Sciences, 40(2), 233-256.

Ulutaş, Ö. (2009). An investigation of pre-service elementary science teachers' scientific literacy level and their attitudes towards science. Yayınlanmamış Yüksek Lisans Tezi, Orta doğu Teknik Üniversitesi, Ankara.

Wei, B. \& Thomas, G. P. (2006). An examination of the change of the junior secondary school chemistry curriculum in the china: in the view of scientific literacy. Research in Science Education, 36, 403-418. 
Wilkinson, J. (1999). Quantitative analysis of physics textbooks for scientific literacy themes. Research in Science Education, 29(3), 385-399.

Yetişir, M. İ. (2007). İlköğretim fen bilgisi öğretmenliği ve sinıf öğretmenliği birinci slnıfinda okuyan ögretmen adaylarının fen ve teknoloji okuryazarlık düzeyleri, Yayınlanmamış Doktora Tezi, Gazi Üniversitesi, Ankara.

Yılmaz S., Dericioğlu T., Elliott I. A., Özden M. S. (2007). Kalkınma Birliklerinden Kalkınma Ajanslarına Yönelirken, 12.Ulusal Bölge Bilimi Planlama Kongresi, İstanbul. 


\section{Extended Summary}

\section{Introduction}

The question "What is science?" is a question on whose answer scientists have had difficulty in agreeing for ages. The reason for not agreeing on a common definition of science is the fact that science has a multifaceted and dynamic structure that is constantly evolving and does not have a limit on the issues that it covers (Doğan, Çakıroğlu, Bilican and Çavuş, 2012). The rapid development of science and technology in the nineteenth century, called the information age, brought many changes in the structure of societies and made education obliged to keep up with this rapid development. In particular, after the 1950s, administrations of many countries have seen scientific knowledge as the key to the future economic race and attempted to raise the knowledge and skills of the individuals who formed the society (Rodrigues and Oliveira, 2008). With the 21st century, states feel the need to follow the rapid developments in science and technology and to keep up with them. Information societies have attached great importance to these developments for the benefit of their future. Countries that find this important want to train and educate their young people as individuals who are constantly in change and development, who follow science, are aware of innovations and developments, who think about how these developments will contribute to them and who can put them into practice (Özdem, Çavaş, Çavaş, Çakıroğlu and Ertepınar, 2010). Each country has determined certain criteria to educate their citizens in compliance with their own cultures and sociological structures and national policies and thus set a target student profile. Students with this profile are called literate individuals. It is thought that especially one of the literacy types, science literacy, can play a very important role for individuals to gain a better understanding of their environment, to maintain their lives more meaningfully by establishing a relationship between science and everyday life, to contribute to scientific culture and to increase the development level of their society by taking an active role in the society. For this reason, the training of science literate individuals through science education programs has become the priority of many countries around the world (Turgut, 2007).

\section{Method}

The purpose of the current study is to determine the universal literacy level of pre-service science teachers attending different Turkish statistical regional units and to determine the effect of the statistical regional unit, gender and grade level variables on the universal science literacy level. The current study was conducted on 1088 (54.2\%) first-year students and 920 (45.8\%) fourth-year students; a total of 2008 students, enrolled at the science teaching departments in the education faculties of 20 universities located in 12 different statistical regions of Turkey in the spring term of 2015-2016 academic year. As the data collection tool, the 48-item "Globally Scientific Literacy Questionaire" (GSLQ) developed by Mun et al. (2015) and adapted to Turkish by Çelik and Can (2017) was used. In the GSLQ scale, the sub-dimensions of Cognitive Habit, Science as Human Endeavour and Metacognition and Self-control have 13 items each while the sub-dimension of Character and Values has 9 items.

\section{Results and Discussion}

The findings of the current study have revealed that the participating pre-service teachers' levels of universal science literacy are high in four sub-dimensions. This shows that the pre-service science teachers are universal science literates with high affective characteristics. Chin (2005) concluded that pre-service classroom and science teachers' basic literacy level is satisfactory in the sub-dimensions of the nature of science, science-technology-society and content knowledge. There is some research in the literature reporting that pre-service science teachers' science literacy level is medium (Bacanak, 
2002; Ulutaş, 2009). On the other hand, their literacy level for the sub-dimension of characters and values was found to be lower than the other sub-dimensions and their literacy level for the subdimension of science as human endeavor was found to be higher than the others. More clearly, the pre-service teachers seem to be more sophisticated in terms of more effective use of scientific knowledge in the process of decision-making, selecting and problem solving while less sophisticated in terms of ecological world view/social and moral conscience and social-scientific responsibility. The study conducted by Chin (2005) in which pre-service teachers' science literacy level was found to be high in the sub-dimensions of the nature of science and science-technology-society concurs with the current study reporting high level of science literacy in relation to the subject of the characteristic of science and society/scientific knowledge.

When the findings are evaluated in terms of the Turkish statistical regional units, it is seen that the universal literacy levels of the students from the education faculties of the universities located in Western Marmara, Central Anatolia and Western Black Sea regions are low in all the subdimensions in general while the universal literacy levels of the students from the education faculties of the universities located in Eastern Marmara, Mediterranean and Middle Eastern Anatolia are generally high in all the sub-dimensions.

Moreover, the gender was found to have a significant effect on the sub-dimensions of character and values and science as human endeavor and this effect is in favor of the female participants. The reason proposed for this in the literature is that female pre-service teachers have higher interest in and curiosity about science courses than male pre-service teaches. Mun, Lee et al. (2013) conducted a study on a total of 646 students; 198 students from Australia, 230 students from China and 218 students from South Korea, by using the universal literacy scale. Their findings revealed that the female participants are better at accepting criticism, paying attention to group objectives and establishing empathy with nature and human beings than the male participants. Finally, the grade level was found to have a significant effect on the sub-dimensions of character and values and metacognition and self-control and this effect is in favor of the fourth-year students. This is highly promising for the 2013 and 2018 science curriculums. 